\title{
Development of a Ferritic Alloy Separator for a Planar SOFC
}

\author{
Shunsuke TANIGUCHI*, Masataka KADOWAKI, Takashi YASUO, \\ Yukinori AKIYAMA, Yasuo MIYAKE and Koji NISHIO
}

Received February 21, 1997 ; Accepted April 4, 1997

\begin{abstract}
Heat-resistant ferritic alloys were investigated for use as a SOFC separator material in order to reduce the difference in thermal expansion between the electrolyte and separator. The heat resistance of ferritic alloys was improved by adding a small amount of lanthanum, making it possible to use them as a SOFC separator. The thermal cycle characteristics were improved in a $50 \mathrm{~mm} \times 50 \mathrm{~mm}$ single cell using this ferritic alloy in comparison with a cell using an Ni-based alloy. The single cell was operated for about $7000 \mathrm{~h}$. Degradation of the cell performance was apparently mainly caused by gas leakage.
\end{abstract}

\section{INTRODUCTION}

Planar-type solid oxide fuel cells (SOFCs) have received a great deal of attention because of their simple manufacturing process and the promise of a higher power density than that available from corresponding tubular designs.

For the separator material, a heat-resistant alloy offers good performance in terms of heat conductivity, mechanical strength and ease of manufacturing. Furthermore, its material cost is much lower than $\mathrm{LaCrO}_{3}$-based ceramics. Among heat-resisting alloys, nickel-based austenitic alloys have mainly been used so far. However, their thermal expansion coefficient does not match that of

New Materials Research Center, SANYO Electric Co., Ltd (1-1 Dainichi-higashimachi, Moriguchi City, Osaka 570, Japan)

Key Words: Solid oxide fuel cells, Ferritic alloy, Separator the electrolyte (zirconia). The difference in thermal expansion between the electrolyte and the separator may adversely affect the thermal cycle characteristics of the SOFC module.

Iron-based ferritic alloys have a lower thermal expansion coefficient than nickelbased austenitic alloys. Therefore, the thermal cycle characteristics of the module are expected to be better with ferritic alloy separators than with austenitic alloy separators. Furthermore, the material cost for ferritic alloys is lower than that for austenitic alloys. However, the heat resistance of ferritic alloys is generally considered to be inferior to that of austenitic alloys. In this paper, the heat resistance of ferritic alloys in the SOFC operating condition was studied and cell performance with a ferritic alloy separator was examined. 
Table 1 Specifications of the alloys used in this study.

\begin{tabular}{|c|c|c|c|c|c|c|c|c|c|c|}
\hline \multirow{2}{*}{ Alloy } & \multicolumn{9}{|c|}{ Chemical composition $/ \mathrm{wt} \%$} & \multirow{2}{*}{$\begin{array}{l}\text { Thermal expansion coefficien } \\
\qquad \mathrm{K}^{-1}(303 \mathrm{~K}-1273 \mathrm{~K})\end{array}$} \\
\hline & $\mathrm{C}$ & $\mathrm{Si}$ & $\mathrm{Mn}$ & $\mathrm{Ni}$ & $\mathrm{Cr}$ & $\mathrm{Al}$ & $\mathrm{Ti}$ & $\mathrm{Fe}$ & $\mathrm{La}$ & \\
\hline A & 0.03 & 0.19 & 0.42 & Bal. & 16.18 & 0.20 & 0.33 & 8.96 & - & $16.7 \times 10^{-6}$ \\
\hline B & 0.05 & 0.39 & 0.51 & 0.25 & 19.24 & 0.14 & 0.50 & Bal. & - & $13.0 \times 10^{-6}$ \\
\hline $\mathrm{C}$ & 0.02 & 0.40 & 0.55 & 0.23 & 22.03 & 0.13 & 0.51 & Bal. & - & $13.0 \times 10^{-6}$ \\
\hline $\mathrm{D}$ & 0.03 & 0.38 & 0.55 & 0.25 & 25.75 & 0.16 & 0.54 & Bal. & - & $13.0 \times 10^{-6}$ \\
\hline $\mathrm{E}$ & 0.02 & 0.38 & 0.52 & 0.24 & 21.81 & 0.16 & 0.59 & Bal. & 0.03 & $12.7 \times 10^{-6}$ \\
\hline F & 0.02 & 0.40 & 0.51 & 0.25 & 21.20 & 0.08 & - & Bal. & - & $13.0 \times 10^{-6}$ \\
\hline
\end{tabular}

\section{EXPERIMENTAL}

\subsection{Heat resistance of ferritic alloys}

The specifications of the alloys used in this study are shown in Table 1 . These alloys were made by vacuum casting and forging. They were made by Hitachi Metals, Ltd. Alloy $\mathrm{A}$ is a nickel-based alloy equivalent to INCONEL 600, and the others are iron-based ferritic alloys. The thermal expansion coefficient of each alloy was measured between $303 \mathrm{~K}$ and $1273 \mathrm{~K}$. To examine the heat resistance of these alloys, they were heated at $1273 \mathrm{~K}$ or $1323 \mathrm{~K}$ in air for the prescribed number of hours, then the weight change was measured and a cross-section of the surface oxide layer was observed. The cross-sectional observation was performed by scanning electron microscopy (SEM) and electron probe microanalysis (EPMA). The electrical resistance of the surface oxide layer of the alloy was measured at $1273 \mathrm{~K}$ in air for the samples that had been heat-treated at $1273 \mathrm{~K}$ in air for $1000 \mathrm{~h}$.

2.2 Cell performance with a ferritic alloy separator

A $50 \mathrm{~mm} \times 50 \mathrm{~mm}$ single cell with a ferritic alloy separator was constructed as follows. The separator was made from alloy $\mathrm{E}$ using a machining process. The electrolyte was made from $\mathrm{PSZ}$ ( $3 \mathrm{~mol}_{\%} \mathrm{Y}_{2} \mathrm{O}_{3}+97 \mathrm{~mol} \%$

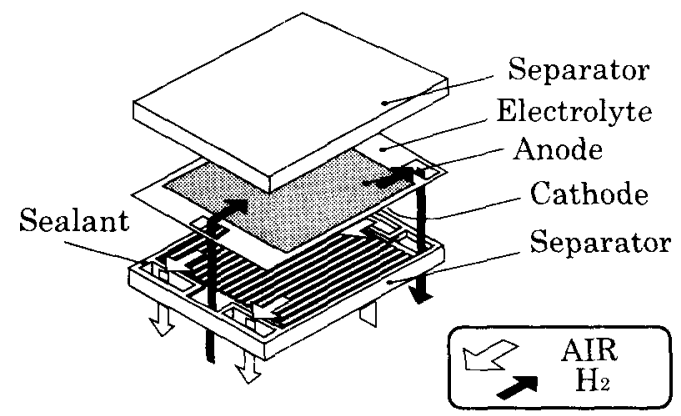

Fig. 1 Schematic diagram of the $50 \mathrm{~mm} \times$ $50 \mathrm{~mm}$ single cell.

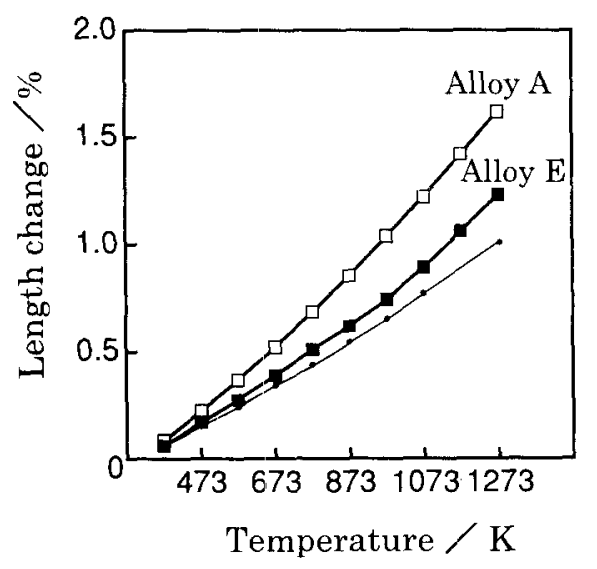

Fig. 2 Thermal expansion of alloys A, E and yttria-doped zirconia. ( • ); $10 \mathrm{~mol} \% \mathrm{Y}_{2} \mathrm{O}_{3}-90 \mathrm{~mol} \% \mathrm{ZrO}_{2}$. 


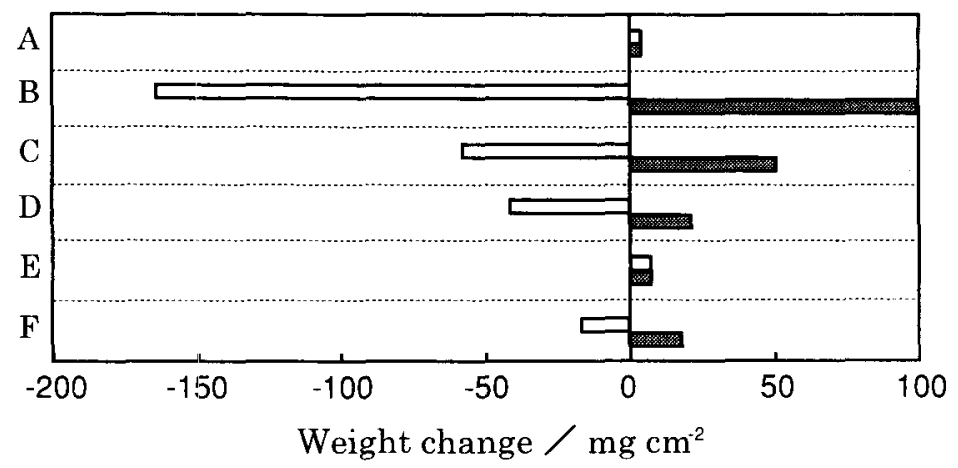

Fig. 3 Weight change in alloys after heating at $1273 \mathrm{~K}$ in air for $1000 \mathrm{~b}$.

Not including the weight of scale exfoliation.

Including the weight of scale exfoliation.

$\mathrm{ZrO}_{2}$ ) and had a thickness of $200 \mu \mathrm{m}$. The anode material consisted of $\mathrm{NiO}$ (Particle size, $\mathrm{d}=1 \mu \mathrm{m}), 56 \mathrm{wt} . \%+\mathrm{YSZ}\left(8 \mathrm{~mol} \% \mathrm{Y}_{2} \mathrm{O}_{3}\right.$ $+92 \mathrm{~mol} \% \mathrm{ZrO} 2, \mathrm{~d}=0.5 \mu \mathrm{m}), 44$ wt. $\%$ was painted on the surface of the electrolyte.

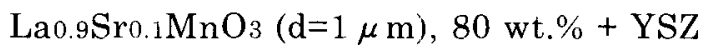
$(\mathrm{d}=0.5 \mu \mathrm{m}), 20 \mathrm{wt} . \%$ was used for the cathode material. It was painted on the other side and then sintered at $1573 \mathrm{~K}$ for $2 \mathrm{~h}$. La0.9Sro.1MnO $3(\mathrm{~d}=1 \mu \mathrm{m}), 90 \mathrm{wt} . \%+\mathrm{La}_{2} \mathrm{O}_{3}$ $(d=0.5 \mu \mathrm{m}), 10 \mathrm{wt} . \%$ was used for the cathode's second layer material. It was painted on the cathode. This layer plays a role in suppressing the chromium diffusion from the alloy separator to the cathode. La0.9Sr0.1 $\mathrm{CoO}_{3}(\mathrm{~d}=1 \mu \mathrm{m})$ was used for the cathode current collecting layer material. It was painted on the cathode's second layer. A slurry made of $\mathrm{La}_{0.9} \mathrm{Sr}_{0.1} \mathrm{CoO}_{3}(\mathrm{~d}=1 \mu \mathrm{m})$ powder was painted on the surface of the cathode side of the separator. Alkaline earth borosilicate glass was used for the sealant.

A schematic diagram of the single cell is presented in Fig. 1. The single cell was operated at a constant current density of 0.3 $\mathrm{A} / \mathrm{cm}^{2}$ at $1173 \mathrm{~K}$ or $1273 \mathrm{~K}$ with air (cathode) and $\mathrm{H}_{2}+3 \% \mathrm{H}_{2} \mathrm{O}$ (anode) gas.

\section{RESULTS AND DISCUSSION}

\subsection{Heat resistance of ferritic alloys}

Figure 2 shows the thermal expansion of alloys $\mathrm{A}, \mathrm{E}$ and yttria-doped zirconia. Alloy $\mathrm{E}$ (ferritic alloy) has a body-centered cubic structure and its thermal expansion coefficient is lower than that of alloy $\mathrm{A}$ (austenitic alloy), which has a face-centered cubic structure. Therefore, the difference in the thermal expansion between the electrolyte and separator becomes smaller with alloy $\mathrm{E}$ than with alloy $\mathrm{A}$.

Figure 3 shows the weight change of these alloys after heating at $1273 \mathrm{~K}$ in air for 1000 $\mathrm{h}$. In this figure, the gray bar indicates the weight increase including the weight of scale exfoliation, and the difference between the gray bar and the white bar indicates the weight of the scale exfoliation. The weight increase and scale exfoliation for ferritic alloys B, C, D and F are large in comparison with alloy $\mathrm{A}$. They became smaller with an increase in chromium content (alloys B, C and D) and with the removal of titanium 


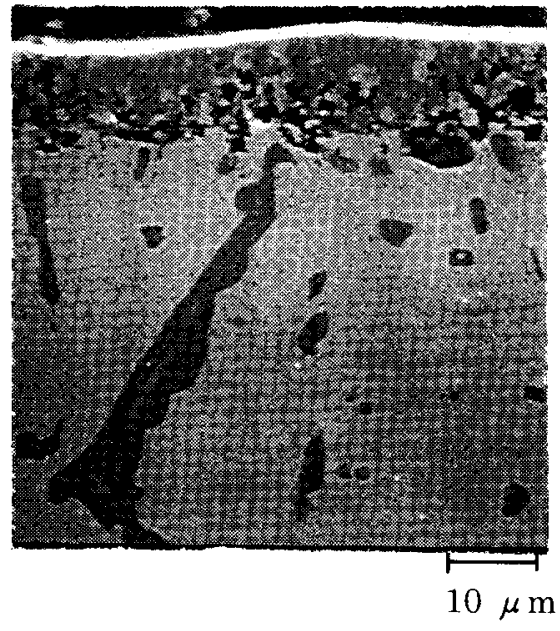

Fig. 4 SEM image of the surface oxide layer of alloy $\mathrm{E}$ after heating at $1323 \mathrm{~K}$ in air for $100 \mathrm{~h}$.

(alloy F). Alloy E exhibits good heat resistance, as does alloy $\mathrm{A}$. This result indicates that a small amount of lanthanum had the effect of improving the heat resistance of the ferritic alloy.

It is generally known a dense $\mathrm{Cr}_{2} \mathrm{O}_{3}$ layer is formed on the surface of alloy $A$ which has the effect of suppressing the oxidation of the alloy. Figure 4 shows a cross-sectional SEM image of the surface oxide layer of alloy $\mathrm{E}$ after heating at $1323 \mathrm{~K}$ in air for $100 \mathrm{~h}$. The results of an EPMA analysis of the sample in Fig. 4 are presented in Fig. 5. The surface oxide layer became a complex structure in which the matrix and $\mathrm{Cr}_{2} \mathrm{O}_{3}$ are mixed. Silicon oxide and aluminum oxide appeared between the matrix and the surface layer. This structure seems to improve the adhesion of the surface oxide layer. Heat resistance can apparently be improved by improving the adhesion of the surface oxide layer.

Internal oxidation of titanium and

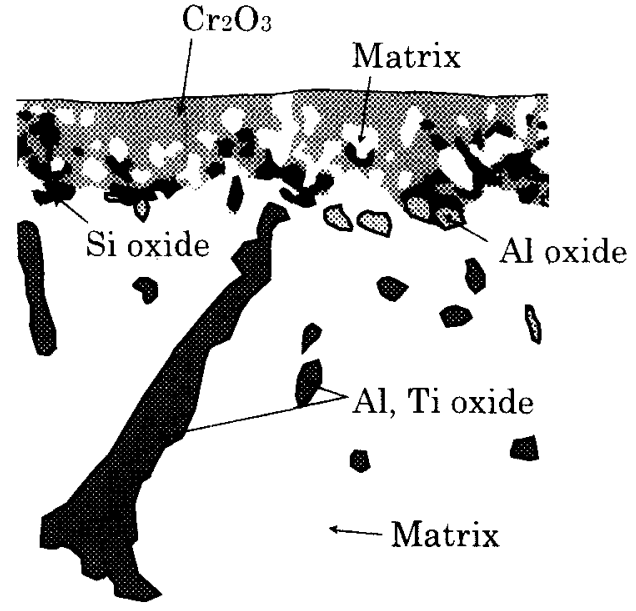

Fig. 5 Microstructure of the surface oxide layer of alloy $\mathrm{E}$ after heating at $1323 \mathrm{~K}$ in air for $100 \mathrm{~h}$.

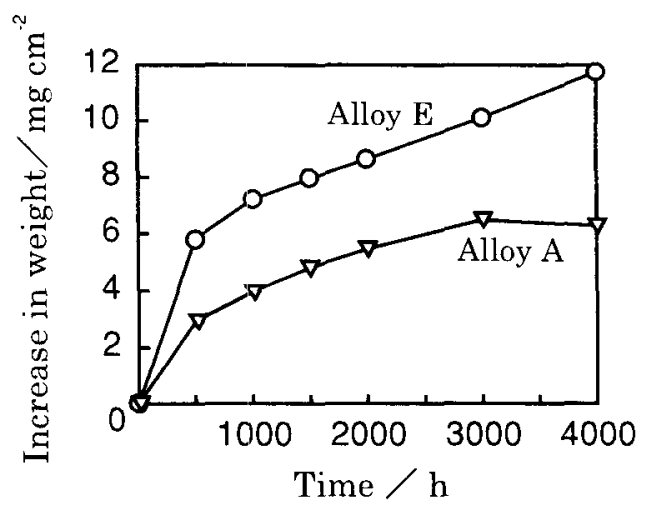

Fig. 6 Weight increase in alloys $\mathrm{A}$ and $\mathrm{E}$ after heating at $1273 \mathrm{~K}$ in air.

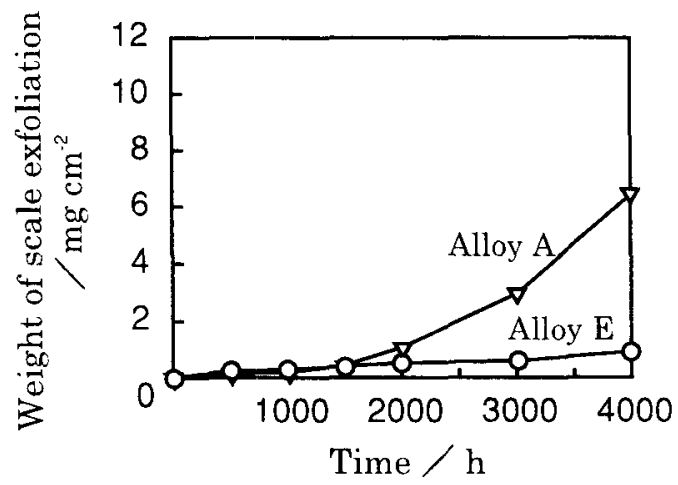

Fig. 7 Weight of scale exfoliation from alloys $\mathrm{A}$ and $\mathrm{E}$ after heating at $1273 \mathrm{~K}$ in air. 


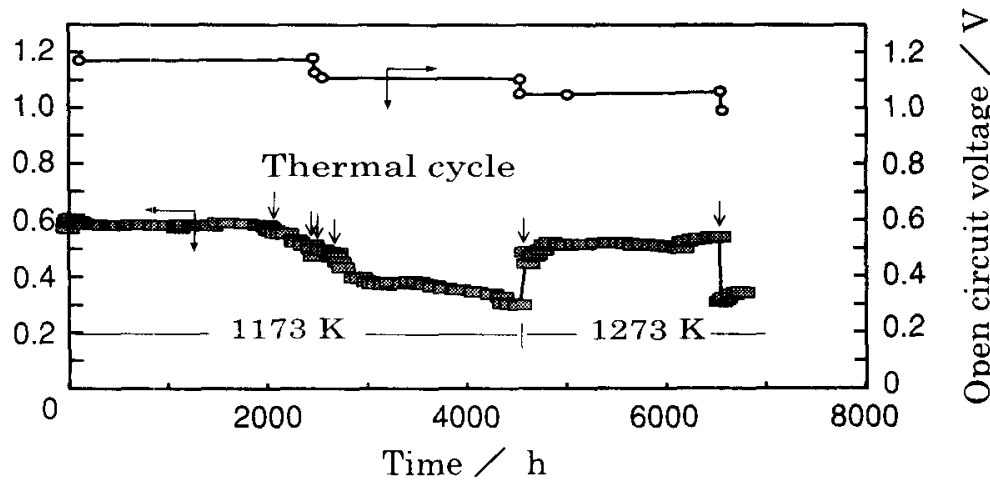

Fig. 8 Cell voltage change for a $50 \mathrm{~mm} \times 50 \mathrm{~mm}$ single cell using alloy $\mathrm{E}$. Current density: $0.3 \mathrm{~A} / \mathrm{cm}^{2}$.

aluminum was observed beneath the surface oxide layer. Titanium might give an adverse effect on the heat resistance of these alloys because it was better without the titanium content (alloy F).

Figure 6 shows the weight increase and Fig. 7 shows the weight of scale exfoliation for alloys $\mathrm{A}$ and $\mathrm{E}$ after heating at $1273 \mathrm{~K}$ in air. The weight increase of alloy $\mathrm{E}$ is larger than that of alloy A. However, the weight of scale exfoliation from alloy $\mathrm{E}$ is smaller than that from alloy A after $2000 \mathrm{~h}$. Thus, the adhesion of the surface oxide layer of alloy $\mathrm{E}$ is better than that of alloy $\mathrm{A}$. The electrical resistance of the surface oxide layer of alloys $\mathrm{A}$ and $\mathrm{E}$ after $1000 \mathrm{~h}$ was $0.018 \Omega \mathrm{cm}^{2}$ and $0.017 \Omega \mathrm{cm}^{2}$. On the assumption that oxidation follows the parabolic rate law and no scale exfoliation occurs, the estimated values of the weight increase and electrical resistance of the surface oxide layer after $40000 \mathrm{~h}$ for alloy $\mathrm{E}$ are $\sim 40 \mathrm{mgcm}^{-2}$ and $~$ $0.1 \Omega \mathrm{cm}^{2}$. However, scale exfoliation may occur in the progress of oxidation, and the oxidation may be accelerated. Therefore,

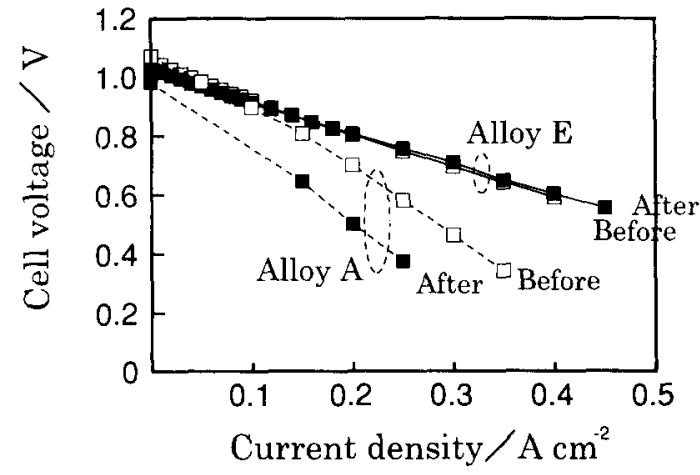

Fig. 9 Thermal cycle characteristics for cells using alloys $\mathrm{A}$ and $\mathrm{E}$. Temperature: $1273 \mathrm{~K}$.

surface treatment for the alloy is necessary for practical use.

3.2 Cell performance with a ferritic alloy separator

Figure 8 shows the change in cell voltage for a single cell using alloy $\mathrm{E}$. The operating temperature was $1173 \mathrm{~K}$ from initial to 4600 $\mathrm{h}$, and it was raised to $1273 \mathrm{~K}$ after $4600 \mathrm{~h}$. In this figure, the arrows indicate thermal cycles from the operating temperature to room temperature. Cell performance before and after the thermal cycle at $2551 \mathrm{~h}$ is 
shown in Fig. 9. In order to allow comparison with the data for alloy $\mathrm{A}$, the operating temperature was raised to $1273 \mathrm{~K}$ at this time. In the case of alloy A, the open circuit voltage (OCV) decreased by more than 100 $\mathrm{mV}$ after the thermal cycle, and the cell voltage also decreased. This was caused by the cracking of the electrolyte. This crack is believed to develop due to the difference in thermal expansion between the electrolyte, the sealant and the separator. On the other hand, the cell voltage change was small with alloy $\mathrm{E}$. This is apparently caused by the decrease in the thermal expansion difference between the electrolyte and the separator, which suppresses the cracking of the electrolyte.

However, OCV decreased gradually with a repetition of the thermal cycles, and the cell performance degraded. This result indicates that gas leakage increased due to the thermal cycles. One crack was observed on the electrolyte after the cell was broken apart. Thus, the improvement of the thermal cycle characteristics of the cell was insufficient. The authors found that the thermal cycle characteristics of the cell can be improved by using ceramic fiber for the sealant instead of glass ${ }^{1}$. This is apparently because the electrolyte and the separator are not bound, and the stress of the electrolyte is reduced. For further improvement, it is necessary to combine this kind of sealant with a ferritic alloy separator.

Another factor in cell performance degradation is thought to be chromium diffusion from the alloy to the cathode. This is because the cell performance gradually degraded from $2700 \mathrm{~h}$ to $4600 \mathrm{~h}$ at $1173 \mathrm{~K}$ and its degradation became smaller after
$4600 \mathrm{~h}$ at $1273 \mathrm{~K}$. It is already known that cell degradation induced by chromium deposition at the cathode/electrolyte interface is severer at lower temperature because of the higher polarization at the interface ${ }^{2)}$. Surface treatment for the alloy is also necessary to suppress the chromium diffusion from the alloy for practical use.

\section{CONCLUSIONS}

The heat resistance of ferritic alloys was improved by adding a small amount of lanthanum content, making it possible to use them as a SOFC separator. The heat resistance was apparently improved by improving the adhesion of the surface oxide layer due to the rare earth addition. The thermal cycle characteristics were improved in a $50 \mathrm{~mm} \times 50 \mathrm{~mm}$ single cell using the ferritic alloy in comparison with a cell using an Ni-based alloy. To further improve the thermal cycle characteristics, it is apparently necessary to improve the sealant in addition to adopting the ferritic alloy separator.

A part of this work was performed as an R\&D program of the New Energy and Industrial Technology Development Organization (NEDO) under the New Sunshine Project of the Agency of Industrial Science and Technology, MITI.

\section{References}

1) M. Kadowaki, Y. Akiyama, T. Yasuo, S. Taniguchi, Y. Itoh, Y. Miyake, and K. Nishio, Proc. 2nd IFCC, 4-03 (1996).

2) S. Taniguchi, M. Kadowaki, T. Yasuo, Y. Akiyama, Y. Itoh, Y. Miyake, and K. Nishio, Denki Kagaku, 64, 568 (1996) 